Jurnal Syntax Imperatif: Jurnal Ilmu Sosial dan

Pendidikan

p-ISSN: 2721-2491 e-ISSN: 2721-2246

Vol, 1. No, 4. September 2020

\title{
Implementasi Technology Acceptance Model dalam Mengukur Penerimaan Operator PTKIS Terhadap Educational Management Information System
}

\section{Ayu Puji Rahayu}

Sekolah Tinggi Agama Islam (STAI) Darul Falah Cihampelas Bandung Barat, Indonesia

Email: ayupujirahayu14@gmail.com

\begin{abstract}
Abstrak
Technology Acceptance Model dalam Mengukur Penerimaan Operator PTKIS terhadap Educational Management Information System. Metode penelitian yang digunakan dalam penelitian adalah studi literatur, observasi, dan wawancara dengan menerapkan model yang akan digunakan dengan objek penelitian adalah PTKIS di wilayah KOPERTAIS II Jawa Barat Banten. Pengolahan data ini terdiri dari 4 tahapan, yaitu: (1) persiapan data mentah, (2) pembuatan model persamaan, (3) validasi model pengukuran, dan (4) pengujian hipotesis. Berdasarkan hasil pengujian terhadap penelitian yang dilakukan di PTKIS Jawa Barat dan Banten tentang tingkat penerimaan operator PTKIS terhadap aplikasi EMIS menggunakan pendekatan model penerimaan teknologi (Technology Acceptance Model) dengan AMOS versi 22.0, kesimpulan yang dapat diambil adalah: Terdapat delapan (8) konstruk/variabel pada penelitian ini yang dianggap dapat menganalisis tingkat penerimaan operator PTKIS terhadap EMIS di Jawa Barat dan Banten. Konstruk/variabel tersebut adalah Perceived Usefulness, Perceived Ease of Use, Behavioral Intention to Use, Attitude Toward Using, Perceived Usage, Experience, Complexity, dan self Efficacy dengan 12 hipotesis yang dibuat untuk menganalisa tingkat penerimaan operator PTKIS di Jawa Barat dan Banten.
\end{abstract}

Kata Kunci: TAM; Tingkat Penerimaan; Operator EMIS

\section{Pendahuluan}

Penggunaan EMIS dalam sistem informasi manajemen pendidikan di lingkungan Kementerian Agama memiliki tujuan sebagai berikut: (1) Memperkuat kemampuan untuk mengatur, merencanakan, dan mengawasi alur informasi antarinstansi yang saling berhubungan; (2) Memadukan seluruh informasi yang berhubungan dengan manajemen kegiatan pendidikan dan menyajikannya secara ringkas dan menyeluruh. Sebagai pusat pendataan Pendidikan Islam satu pintu, EMIS memiliki peran strategis dalam proses perencanaan dan pengambilan kebijakan program Pendis. Namun demikian implementasi EMIS di lapangan masih menemui berbagai kendala. Padahal Kastolan (2016) berpendapat bahwa “....EMIS bisa menjadi sumber utama referensi data di lingkup Ditjen Pendidikan Islam, baik di pusat maupun daerah, sehingga data EMIS harus terupdate secara periodik, data EMIS terjamin kelengkapan, keakuratan, dan ketepatan waktunya, data EMIS dapat dimanfaatkan dan digunakan oleh seluruh pemangku kepentingan untuk berbagai keperluan, terutama untuk mendukung perencanaan dan pengambilan kebijakan." Realitas di lapangan banyak institusi pendidikan khususnya Pendidikan Tinggi menempatkan EMIS bukan sebagai sebuah prioritas, bahkan ada kecenderungan diabaikan. 
Menyikapi kondisi tersebut, hasil survey lapangan yang dilakukan penulis di beberapa PTKIS di salah satu kabupaten di Jawa Barat, implementasi EMIS terkendala berbagai faktor, baik teknis maupun nonteknis. Kondisi tersebut ditandai dengan: 1) banyak PTKIS yang terlambat dalam melakukan pelaporan EMIS; 2) banyak operator PTKIS yang kurang memahami proses bisnis dalam EMIS; 3) operator merasa rumit dalam pengaturan data perguruan tinggi; 4) sering terjadi kesalahan pada saat update data dan; 5) kesulitan dalam sinkronisasi (pengiriman data). Faktor sikap operator dalam implementasi EMIS merupakan faktor nonteknis yang menjadi kendala utama implementasi EMIS. Sikap tidak mau berubah dan cenderung menolak terhadap EMIS sebagai sebuah inovasi dalam pencatatan dan perekeman data perguruan tinggi secara elektronik (berbasis ICT). Beberapa kasus, inovasi berjalan tidak sesuai dengan apa yang diharapkan. Faktor budaya menjadi faktor penghambat terbesar penerapan sebuah inovasi. "Terdapat delapan faktor penghambat dalam sebuah inovasi, salah satunya budaya risk aversion yakni budaya yang tidak menyukai risiko. Sifat inovasi yang memiliki segala risiko termasuk risiko gagal. Pegawai cenderung enggan berhubungan dengan risiko dan memilih untuk melaksanakan pekerjaan secara proseduraladministratif dengan risiko minimal."

(Mulgan \& Albury, 2003, pp. 31-33) Dibutuhkan usaha untuk menanggani budaya risk aversion, agar implementasi TIK berjalan dengan baik. Pendapat senada dikemukakan oleh (Hartono Mustakini Jogiyanto, 2005, pp. 1-2), bahwa "Penyebab kegagalan teknologi informasi, lebih pada aspek keperilakuannya (behavioral), karena perilaku pengguna dari suatu teknologi informasi menjadi salah satu faktor utama dari keberhasilan penerapan suatu sistem informasi/teknologi informasi." Padahal TIK bisa menjadi salah satu kunci sukses dalam pendidikan.

Mengenai implementasi TIK dalam Pendidikan (Tok \& Sora, 2013, pp. 282-285) berpendapat bahwa dengan TIK, kita mampu memenuhi "kebutuhan beradaptasi, memperbaharui pengetahuan, membangun jejaring untuk menemukan pengetahuan, dan menerapkannya dalam situasi yang baru. Melalui TIK kita mampu membuat, menyebarkan, menyimpan, mengevaluasi, mencari, dan mengelola informasi." Implementasi EMIS dalam proses pendidikan, secara teknis menuntut kesiapan para operator PTKIS. Terdapat beberapa faktor yang memengaruhi tingkat kesiapan operator dalam menggunakan EMIS.

Faktor optimisme memiliki korelasi yang sangat kuat dengan inovasi itu sendiri. Adapun rumusan penelitian ini adalah untuk "Bagaimana penerimaan operator PTKIS terhadap EMIS ditinjau dari berbagai konstruk yang menyusun sebuah TAM: Perceived Usage, Behavioral Intention to Use, Attitude Toward Behaviour, Perceived Usefulness, dan Perceived Ease of Useoleh operator PTKIS di Kopertais Wilayah II Jawa Barat dan Banten?"

\section{TECHNOLOGY ACCEPTANCE MODEL (TAM)}

Theory of Acceptance Model (TAM) merupakan adaptasi dari Theory of Reasoned Action Model (TRA) yang secara khusus telah disesuaikan dengan model 
penerimaan sistem informasi oleh pengguna/user (Davis, Bagozzi, \& Warshaw, 1989)TAM memiliki dua sisi yaitu sisi yang pertama atau yang biasa disebut beliefs yang terdiri atas perceived usefulness dan perceived ease of use, dan sisi yang kedua terdiri dari attitude, behavior intention to use, dan usage behavior (Straub, Limayem, \& Karahanna-Evaristo, 1995). Berikut ini adalah gambar tentang TAM.

Gambar 1

Hubungan antarkomponen dalam TAM

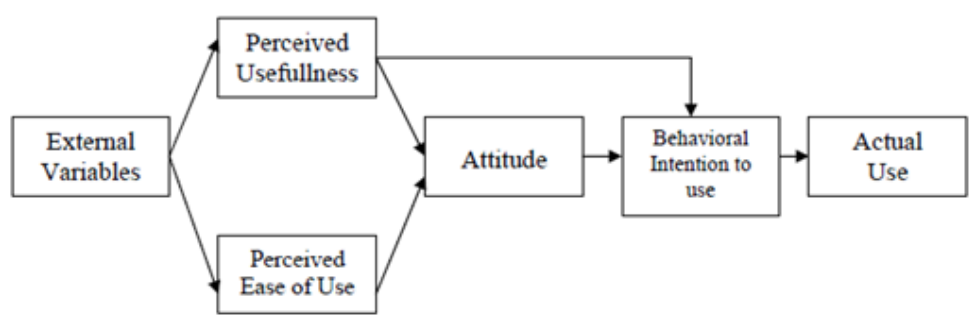

Sumber: Davis (1986) dalam Warshaw et al (1989)

Tingkat penerimaan pengguna teknologi informasi ditentukan oleh enam pembangun, yaitu variabel dari luar (external variable), persepsi pengguna terhadap kemudahan (perceived ease of use), persepsi pengguna terhadap manfaat (perceived usefulness), sikap dalam menggunakan (attitude toward using), perilaku untuk menggunakan (behavioral intention to use), dan pemakaian nyata (actual system usage). (Davis et al., 1989). Terdapat 5 konstruk utama yang menyusun sebuah TAM, yaitu:

\section{Perceived Usefulness (Persepsi Kemanfaatan)}

Perceived Usefulness diartikan sebagai tingkat di mana seseorang percaya bahwa menggunakan sistem tertentu dapat meningkatkan kinerjanya. Beberapa indikator dari konstruk usefulness yaitu:
a. Bekerja lebih cepat (work more quickly)
b. Berguna (useful)
c. Meningkatkan produktivitas (increase productivity)
d. Meningkatkan efektivitas (enhance effectiveness)
e. Meningkatkan performansi kerja (improve job performance)

Banyak penelitian sebelumnya menemukan pengaruh persepsi kemanfaatan terhadap penerimaan teknologi secara umum menyatakan bahwa persepsi kemanfaatan meningkatkan tingkat penerimaan teknologi (Chau \& Hu, 2002) (Gefen, Karahanna, \& Straub, 2003). Penelitian-penelitian sebelumnya banyak menyatakan bahwa Perceived Usefulness lebih penting daripada ease of use ((Davis et al., 1989);(Henderson \& Divett, 2003); (Igbaria, 1994), terutama untuk post-adoption attitude (Karahanna, Straub, \& Chervany, 1999) 
2. Perceived Ease of Use (Persepsi Kemudahan Pengguna)

Perceived ease of use mengacu pada tingkatan sejauh mana individu percaya bahwa teknologi yang akan diadopsi mudah untuk digunakan (less effort). Terdapat beberapa indikator dari konstruk perceived ease of use, yaitu:
a. Mudah untuk dipelajari (ease to learn)
b. Dapat dikendalikan (controllable)
c. Jelas dan dapat dimengerti (clear and understandable)
d. Fleksibel (flexible)
e. Mudah menjadi mahir (easy to become skillfull)
f. Mudah digunakan (ease to use)

Penelitian-penelitian sebelumnya mengungkap bahwa tingkat penerimaan teknologi meningkat seiring meningkatnya tingkat persepsi kemudahan penggunaan (Davis, 1989; Davis dan Venkatesh, 1996; Gefenm Karahama, Straub, 2003; Kaasinen, 2005). Secara umum, persepsi kemanfaatan (usefulness) lebih penting dari pada persepsi kemudahan (ease of use) (Davis, 1993), tapi persepsi kemudahan (ease of use) kadang ditemukan lebih penting daripada persepsi kemanfaatan (usefulness) (Van der Heidjen, 2004).

Perbandingan lainnya dari efek ease of use dan perceived usefulness dilaporkan oleh Karahanna dan Straub (1999). Mereka menemukan bahwa efek ease of use lebih penting untuk pre-adoption attitudes, sedangkan perceived usefulness lebih penting untuk post-adoption attitudes. Secara umum, perceived ease of use dapat memperkuat perceived usefulness.

\section{Attitude Toward Behaviour (Sikap terhadap Perilaku)}

Attitude toward behavior sebagai perasaan positif atau negatif seseorang jika harus melakukan perilaku yang akan ditentukan. Beberapa penelitian menunjukkan sikap (attitude) berpengaruh secara positif terhadap minat perilaku (behavioral intention), akan tetapi beberapa penelitian juga menunjukkan attitude tidak berpengaruh signifikan terhadap minat perilaku, sehingga sebagian penelitian tidak memasukkan konstruk sikap ke dalam model.

\section{Behavioral Intention (Minat Perilaku)}

(Hartono M Jogiyanto, 2007) mengatakan bahwa minat perilaku adalah suatu keinginan (minat) seseorang untuk melakukan suatu perilaku tertentu. Seseorang akan melakukan suatu perilaku jika mempunyai keinginan atau minat untuk melakukannya. Hasil penelitian sebelumnya menunjukkan bahwa minat perilaku merupakan prediksi terbaik dari penggunaan teknologi oleh pengguna sistem. Davis (1989) menyatakan bahwa behavioral intention to use adalah kecenderungan perilaku untuk tetap menggunakan suatu teknologi. Tingkat penggunaan teknologi pada seseorang dapat 
diprediksi dari sikap perhatiannya terhadap teknologi tersebut. Perceived usefulness mempunyai pengaruh signifikan terhadap behavioral intention.

\section{Actual Usage (Penggunaan Sebenarnya Perilaku)}

Perilaku (behavior) adalah tindakan yang dilakukan oleh seseorang. Dalam konteks penggunaan sistem informasi, (Hartono M Jogiyanto, 2007) mengatakan bahwa perilaku (behavior) adalah penggunaan sesungguhnya (actual usage) dari teknologi.

Penelitian-penelitian sebelumnya menyatakan bahwa konstruk perceived usefulness dan perceived ease of use adalah dua faktor utama yang menjabarkan penerimaan dan penggunaan individu terhadap teknologi, perceived usefulness dan perceived ease of use dipengaruhi oleh variabel-variabel eksternal seperti dorongan atau tekanan pihak lain, perubahan lingkungan serta tren di tengah pengguna teknologi, pengalaman, dan banyak faktor eksternal lainnya. Perceived ease of use juga berpengaruh pada perceived usefulness yang dapat diartikan bahwa jika seseorang merasa sistem tersebut mudah digunakan maka sistem tersebut berguna bagi mereka. Kedua konstruk model TAM yaitu kemanfaatan (usefulness) dan kemudahan penggunaan (ease of use) dapat menjelaskan aspek keperilakuan pemakai.

Model TAM yang dikembangkan oleh Davis (1989) mendapat perluasan dari para peneliti, antara lain Chin \& Todd (1995) dan Iqbaria (1997), Chin dan Todd membagi dua faktor pada konstruk kemanfaatan (usefulness) yaitu (1) kemanfaatan dan, (2) efektivitas dengan masing-masing dimensinya sendiri. Persepsi pengguna terhadap manfaat teknologi dapat diukur dari beberapa faktor berikut:

a. Penggunaan teknologi dapat meningkatkan produktivitas pengguna

b. Penggunaan teknologi dapat dapat meningkatkan kinerja pengguna

c. Penggunaan teknologi dapat meningkatkan efisiensi proses yang dilakukan pengguna

Faktor-faktor di atas akan memengaruhi persepsi pengguna terhadap pemanfaatan teknologi. Pada umumnya pengguna akan memiliki persepsi positif terhadap teknologi yang disediakan. Persepsi negatif akan muncul sebagai dampak dari penggunaan teknologi tersebut, artinya persepsi negatif berkembang setelah pengguna pernah mencoba teknologi tersebut atau mempunyai pengalaman buruk terhadap penggunaan teknologi tersebut. Faktor persepsi negatif sebenarnya berkaitan dengan faktor kedua dari TAM yaitu persepsi pengguna terhadap kemudahan penggunaan teknologi. Faktor persepsi pengguna terhadap kemudahan penggunaan teknologi dipengaruhi beberapa faktor:

1. Faktor pertama berfokus pada teknologi itu sendiri, misalnya pengalaman pengguna terhadap penggunaan teknologi sejenis. Pengalaman baik pengguna akan teknologi sejenis akan memengaruhi persepsinya terhadap pemanfaatan teknologi baru yang disediakan, begitu juga sebaliknya. 
2. Reputasi teknologi yang diterapkan. Reputasi teknologi yang baik yang didengar oleh pengguna akan mendorong keyakinan pengguna akan kemudahan penggunaan teknologi tersebut, begitu juga sebaliknya.

3. Tersedianya mekanisme support yang handal. Mekanisme support yang handal akan memengaruhi kepercayaan pengguna akan kemudahan teknologi yang diterapkan.

TAM menjelaskan hubungan antara keyakinan/beliefs (usefulness dan ease of use) dengan sikap/attitude, tujuan, intentions pemakai, serta penggunaan nyata dari sistem. Perceived usefulness didefinisikan oleh (Davis et al., 1989) sebagai suatu tingkat di mana seseorang percaya bahwa penggunaan sistem secara khusus akan meningkatkan kinerjanya. Sedangkan perceived ease of use didefinisikan sebagai suatu tingkat di mana seseorang percaya bahwa penggunaan sistem secara khusus akan mengarah pada suatu usaha. Pengujian penggunaan MS Access mengelompokkan variabel-variabel dalam TAM menjadi 3 kelompok yaitu perceived usefulness dan perceived ease of use sebagai variabel independent, penggunaan sistem secara nyata sebagai variabel dependent dan variabel-variabel mediasinya adalah attitude toward use dan behavioral intention to use (Gardner \& Amoroso, 2004).

(Gardner \& Amoroso, 2004)melakukan studi analisa untuk hasil-hasil penelitian model TAM. Dari hasil studi analisa diperoleh hasil bahwa perceived ease of use menunjukkan hubungan yang signifikan dengan perceived usefulness pada 15 hasil penelitian, tapi ada 2 hasil penelitian yang menunjukkan tidak signifikan. Faktor gender dan pengalaman merupakan faktor eksternal yang berdampak pada perceived usefulness. (Sun \& Zhang, 2006) juga melakukan studi analisa lagi pada 54 artikel jurnal diperoleh hasil sebagai berikut:

a. Construct berbeda-beda, sebagai contoh beberapa studi menggunakan attitude sedangkan yang lain menggunakan behavioral intention dan actual usage sebagai indikator penerimaan pemakai.

b. Untuk beberapa hubungan utama hasilnya tidak konsisten, sebagai contoh pada beberapa penelitian perceived ease of use mempunyai hubungan yang signifikan dengan behavioral intention sedangkan pada beberapa penelitian yang lain tidak.

\section{Metode Penelitian}

Metode penelitian yang dilakukan adalah studi literatur, observasi, dan wawancara dengan menerapkan model yang akan digunakan. Tahapan dari metodologi yang dilakukan untuk melakukan penelitian dengan pendekatan:

Studi literatur, dilakukan untuk mendapatkan pengetahuan yang akan digunakan dalam penelitian. Aktivitas yang dilakukan pada tahap ini adalah mengeksplorasi hasil penelitian-penelitian yang berhubungan dengan penelitian yang akan dilakukan. 
Pembangunan model, pada tahap ini akan dilakukan analisis dimensi sampai dengan variabel untuk penerimaan teknologi yang memengaruhi terhadap penerimaan aplikasi Emis. Modelvalidation, aktivitas yang dilakukan adalah menyebarkan angket di tempat yang menjadi objek penelitian, kemudian data angket tersebut dihitung dengan metode analisis jalur.

\section{Hasil Penelitian}

\section{Hasil Pengolahan Data dan Uji Hipotesis}

Pengolahan data dilakukan setelah data mentah hasil kuesioner telah terkumpul. Pengolahan data ini terdiri dari 4 tahapan, yaitu: (1) persiapan data mentah, (2) pembuatan model persamaan, (3) validasi model pengukuran, dan (4) pengujian hipotesis. Proses pengujian hipotesis dibantu dengan bantuan aplikasi IBM SPSS dan SPSS AMOS 22.0.0.

\section{Pengujian Kuesioner Penelitian}

\section{Pengujian Validitas}

Pengujian dilakukan dengan menggunakan software SPSS versi 20. Besaran koefisien korelasi item total dikoreksi sebesar 0,25 atau 0,30 sebagai batas minimal valid tidaknya sebuah item dan dibandingkan nilai $r$ hitung dengan nilai $r$ tabel (Ghozali, 2005). Kriteria validitas instrumen adalah jika $r$ hitung $>r$ tabel, di mana $r$ tabel didapat dari tabel nilai Product Moment dengan nilai derajat kebebasan aau $\mathrm{df}=\mathrm{n}$ 2 (di mana $\mathrm{n}$ adalah jumlah responden). Pada uji validitas sampel ini diketahui $\mathrm{r}$ tabel dengan tingkat kesalahan $10 \%$ dan df $=30-2 ; 28$ adalah 0,306 . Hasil pengujian dengan SPSS ditunjukkan oleh tabel 1

\section{Tabel 1}

Nilai Corrected Item-Item Correlation Uji Validitas Kuesioner Awal

\begin{tabular}{c|c|c|c|c} 
& $\begin{array}{c}\text { Item-Total Statistics } \\
\text { Item Deleted }\end{array}$ & $\begin{array}{c}\text { Scale Variance } \\
\text { if Item Deleted }\end{array}$ & $\begin{array}{c}\text { Corrected Item- } \\
\text { Total } \\
\text { Correlation }\end{array}$ & $\begin{array}{c}\text { Cronbach's } \\
\text { Alpha if Item } \\
\text { Deleted }\end{array}$ \\
\hline PU1 & 116.80 & 358.993 & .860 & .967 \\
\hline PU2 & 116.77 & 358.254 & .861 & .967 \\
\hline PU3 & 116.73 & 364.754 & .867 & .967 \\
\hline PU4 & 116.63 & 359.757 & .847 & .967 \\
\hline PU5 & 116.93 & 362.064 & .868 & .967 \\
\hline PEU1 & 116.97 & 367.344 & .773 & .968 \\
\hline PEU2 & 116.80 & 372.717 & .584 & .969 \\
\hline PEU3 & 116.93 & 362.892 & .883 & .967 \\
\hline PEU4 & 116.90 & 365.472 & .855 & .967 \\
\hline BIU1 & 117.13 & 368.189 & .763 & .968 \\
\hline BIU2 & 117.13 & 371.982 & .607 & .969 \\
\hline BIU3 & 117.23 & 371.289 & .551 & .969 \\
\hline BIU4 & 117.03 & 371.895 & .690 & .968 \\
\hline BIU5 & 117.13 & 370.947 & .673 & .968 \\
\hline ATU1 & 117.03 & 366.447 & .832 & .967 \\
\hline ATU2 & 117.10 & 364.024 & .903 & .967 \\
\hline ATU3 & 117.13 & 363.361 & .836 & .967 \\
\hline
\end{tabular}




\begin{tabular}{c|l|l|l|l}
\hline ATU4 & 117.80 & 385.614 & .204 & .971 \\
\hline PUs1 & 116.93 & 366.478 & .811 & .967 \\
\hline PUs2 & 117.00 & 368.207 & .779 & .968 \\
\hline PUs3 & 116.93 & 364.547 & .924 & .967 \\
\hline PUs4 & 116.97 & 366.240 & .809 & .967 \\
\hline PUs5 & 117.00 & 368.966 & .800 & .968 \\
\hline PUs6 & 116.83 & 368.764 & .772 & .968 \\
\hline E1 & 116.67 & 375.402 & .683 & .968 \\
\hline E2 & 117.00 & 379.517 & .432 & .969 \\
\hline E3 & 116.90 & 370.714 & .682 & .968 \\
\hline C1 & 117.43 & 390.185 & .348 & .972 \\
\hline C2 & 117.33 & 376.782 & .495 & .969 \\
\hline C3 & 117.57 & 389.702 & .351 & .972 \\
\hline CSE1 & 116.83 & 373.040 & .668 & .968 \\
\hline CSE2 & 116.77 & 369.289 & .788 & .968 \\
\hline CSE3 & 116.97 & 368.240 & .787 & .968
\end{tabular}

Berdasarkan hasil perhitungan dan perbandingan dengan $r$ tabel, terdapat 1 item pertanyaan yang tidak valid karena tidak memenuhi kriteria koefisien yang ditunjukkan pada tabel 2

\section{Tabel 2}

Item Kuesioner yang direduksi

\begin{tabular}{c|c|c|c} 
Item & $\begin{array}{c}\text { Corrected } \\
\text { item-total } \\
\text { Correlation }\end{array}$ & $\begin{array}{c}\text { Cronbach's } \\
\text { Alpha if Item } \\
\text { deleted }\end{array}$ & \multicolumn{1}{|c}{ Pertanyaan kuesioner } \\
\hline ATU4 &, 204 &, 971 & $\begin{array}{l}\text { Menggunakan aplikasi EMIS membuat } \\
\text { saya bosan }\end{array}$
\end{tabular}

\section{Pengujian Reliabilitas}

Reliabilitas adalah ukuran yang menunjukkan bahwa alat ukur yang digunakan dalam penelitian keperilakuan mempunyai keandalan sebagai alat ukur, diantaranya di ukur melalui konsistensi hasil pengukuran dari waktu ke waktu jika fenomena yang diukur tidak berubah. Reliabilitas menyangkut masalah ketepatan alat ukur. Suatu instrumen dianggap reliabel apabila instrument tersebut dapat dipercaya sebagai alat ukur penelitian. Cronbach'alpha merupakan koefisien reliabilitas yang mengindikasikan beberapa baik sebuah item dalam set berkorelasi positif satu sama lainnya. Nilai koefisien yang semakin mendekati 1 menunjukkan konsistensi internal yang semakin baik dan nilai koefisien cronbach's alpha> 0.8 merupakan hasil yang baik.

Tabel 3.

Hasil Reliabilitas Kuesioner Awal

\section{Reliability Statistics}

\begin{tabular}{r|r}
\hline $\begin{array}{c}\text { Cronbach's } \\
\text { Alpha }\end{array}$ & N of Items \\
\hline .969 & 33
\end{tabular}




\section{Pengujian Ulang Hasil Modifikasi}

Setelah item yang tidak valid direduksi, dilakukan pengujian ulang terhadap itemitem yang tersisa. Dari hasil pengujian menggunakan SPPS 20, menunjukkan adanya peningkatan koefisien cronbach's alpha setelah adanya pengurangan item yang tidak valid dari semulanya 0,969 menjadi 0,971. Peningkatan ini menunjukkan kuesioner yang dimodifikasi menjadi lebih reliabel.

Tabel 4.

Hasil Uji Reliabilitas Kuesioner Awal Modifikasi

\section{Reliability Statistics}

\begin{tabular}{r|r}
\hline $\begin{array}{c}\text { Cronbach's } \\
\text { Alpha }\end{array}$ & N of Items \\
\hline .971 & 32
\end{tabular}

Hasil uji validitas setiap item yang sudah dimodifikasi menunjukkan bahwa semua item pertanyaan memiliki nilai cronbach's alpha lebih besar dari 0,306 dan masuk dalam kriteria valid.

Tabel 5.

Validitas Kuesioner Awal Modifikasi Item-Total Statistics

\begin{tabular}{|c|c|c|c|c|}
\hline & $\begin{array}{l}\text { Scale Mean if } \\
\text { Item Deleted }\end{array}$ & $\begin{array}{l}\text { Scale Variance } \\
\text { if Item Deleted }\end{array}$ & $\begin{array}{c}\text { Corrected Item- } \\
\text { Total } \\
\text { Correlation } \\
\end{array}$ & $\begin{array}{c}\text { Cronbach's } \\
\text { Alpha if Item } \\
\text { Deleted } \\
\end{array}$ \\
\hline PU1 & 113.93 & 351.995 & .862 & .969 \\
\hline PU2 & 113.90 & 351.334 & .861 & .969 \\
\hline PU3 & 113.87 & 357.706 & .870 & .969 \\
\hline PU4 & 113.77 & 352.806 & .847 & .969 \\
\hline PU5 & 114.07 & 354.892 & .875 & .969 \\
\hline PEU1 & 114.10 & 360.162 & .779 & .969 \\
\hline PEU2 & 113.93 & 365.513 & .589 & .970 \\
\hline PEU3 & 114.07 & 355.926 & .883 & .969 \\
\hline PEU4 & 114.03 & 358.240 & .863 & .969 \\
\hline BIU1 & 114.27 & 361.030 & .768 & .969 \\
\hline BIU2 & 114.27 & 364.754 & .612 & .970 \\
\hline BIU3 & 114.37 & 363.757 & .564 & .971 \\
\hline BIU4 & 114.17 & 364.557 & .701 & .970 \\
\hline BIU5 & 114.27 & 363.651 & .681 & .970 \\
\hline ATU1 & 114.17 & 359.385 & .834 & .969 \\
\hline ATU2 & 114.23 & 357.013 & .905 & .969 \\
\hline ATU3 & 114.27 & 356.133 & .844 & .969 \\
\hline PUs1 & 114.07 & 359.444 & .812 & .969 \\
\hline PUs2 & 114.13 & 360.947 & .788 & .969 \\
\hline PUs3 & 114.07 & 357.582 & .924 & .969 \\
\hline PUs4 & 114.10 & 359.197 & .811 & .969 \\
\hline PUs5 & 114.13 & 361.706 & .809 & .969 \\
\hline PUs6 & 113.97 & 361.482 & .781 & .969 \\
\hline E1 & 113.80 & 368.441 & .679 & .970 \\
\hline E2 & 114.13 & 372.533 & .427 & .971 \\
\hline E3 & 114.03 & 364.033 & .671 & .970 \\
\hline $\mathrm{C} 1$ & 114.57 & 384.047 & .319 & .974 \\
\hline $\mathrm{C} 2$ & 114.47 & 369.982 & .486 & .971 \\
\hline C3 & 114.70 & 383.666 & .322 & .974 \\
\hline
\end{tabular}




\begin{tabular}{lllll}
\hline CSE1 & 113.97 & 366.033 & .666 & .970 \\
\hline CSE2 & 113.90 & 362.231 & .790 & .969 \\
\hline CSE3 & 114.10 & 361.266 & .785 & .969
\end{tabular}

Tahapan ini melakukan pengujian model persamaan struktural yang telah dibuat dengan menggunakan Structural Equation Modeling (SEM). Pengolahan data model tersebut menggunakan model analisis faktor konfirmasi (Confirmatory factor analysis) yang dibantu dengan aplikasi SPSS AMOS versi 22. Model yang dibuat adalah seperti terlihat pada gambar berikut.

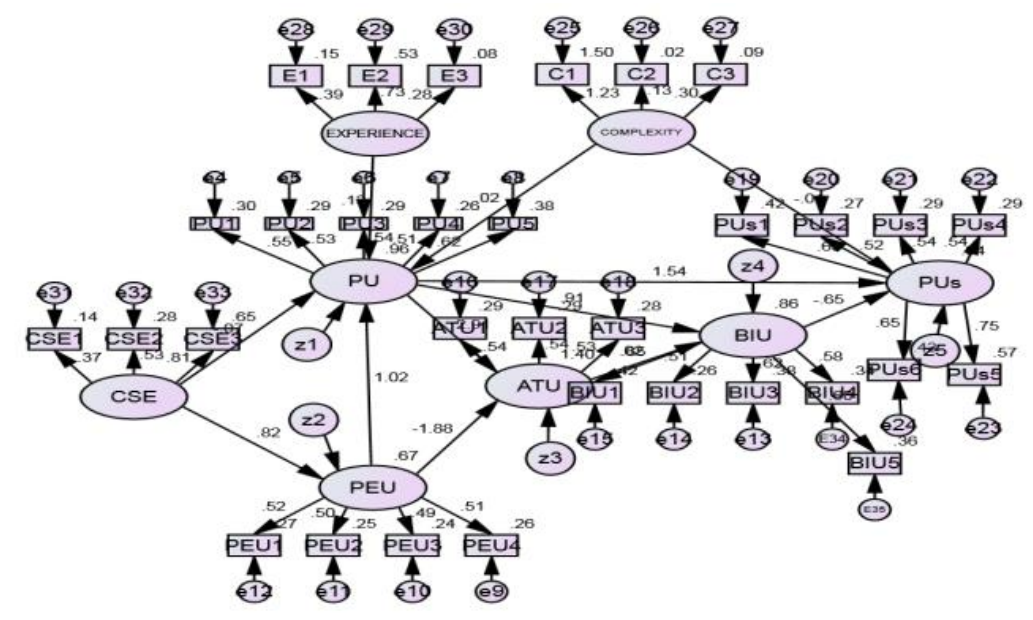

Gambar 1.

Keterkaitan konstruk dan indikator disesuaikan dengan hipotesis penelitian

Gambar 1 model penelitian secara keseluruhan seperti terlihat pada gambar di atas memperlihatkan bahwa model terdiri atas 8 konstruk, yaitu PU (Perceived Usefulness), PEU (Perceived Ease of Use), BIU (Behavioral Intention to Use), ATU (Attitude Toward Using), PUs (Perceived Usage), E (Experience), C (Complexity), dan CSE (Computer Self Efficacy). Pada model ini, keterkaitan antarkonstruk dan keterkaitan antarindikator disesuaikan dengan hipotesis penelitian dan hasil pengujian model tiap konstruk. Konstruk E, C, dan CSE merupakan konstruk eksogen yang merupakan konstruk yang memengaruhi konstruk PU, PEU, BIU, ATU dan PUs. PU, PEU, ATU, dan BIU merupakan konstruk yang bersifat eksogen dan endogen, artinya konstruk tersebut dipengaruhi dan memengaruhi konstruk lain. Variabel error perlu ditambahkan didalam setiap indikator dan konstruk yang bersifat endogen. Hasil pengujian dengan SPSS AMOS versi 22 adalah seperti yang tertera pada tabel berikut.

\section{Tabel 6}

OutputRegression Weights

Estimate S.E. C.R. P Signifikansi

\begin{tabular}{lllrrrll}
\hline PEU & $<--$ & CSE & 1.327 & .474 & 2.801 & .005 & Signifikan \\
\hline PU & $<---$ & CSE & -.128 & .285 & -.449 & .654 & Tidak Signifikan \\
\hline PU & $<---$ & EXPERIENCE & .184 & .132 & 1.390 & .164 & Tidak Signifikan \\
\hline PU & $<---$ & COMPLEXITY & .011 & .027 & .393 & .694 & Tidak Signifikan \\
\hline PU & $<---$ & PEU & 1.187 & .334 & 3.553 & $* * *$ & Signifikan \\
\hline ATU & $<---$ & PU & 2.644 & 1.366 & 1.936 & .053 & Signifikan \\
\hline ATU & $<---$ & PEU & -1.980 & 1.532 & -1.292 & .196 & Tidak Signifikan
\end{tabular}


Estimate S.E. C.R. P Signifikansi

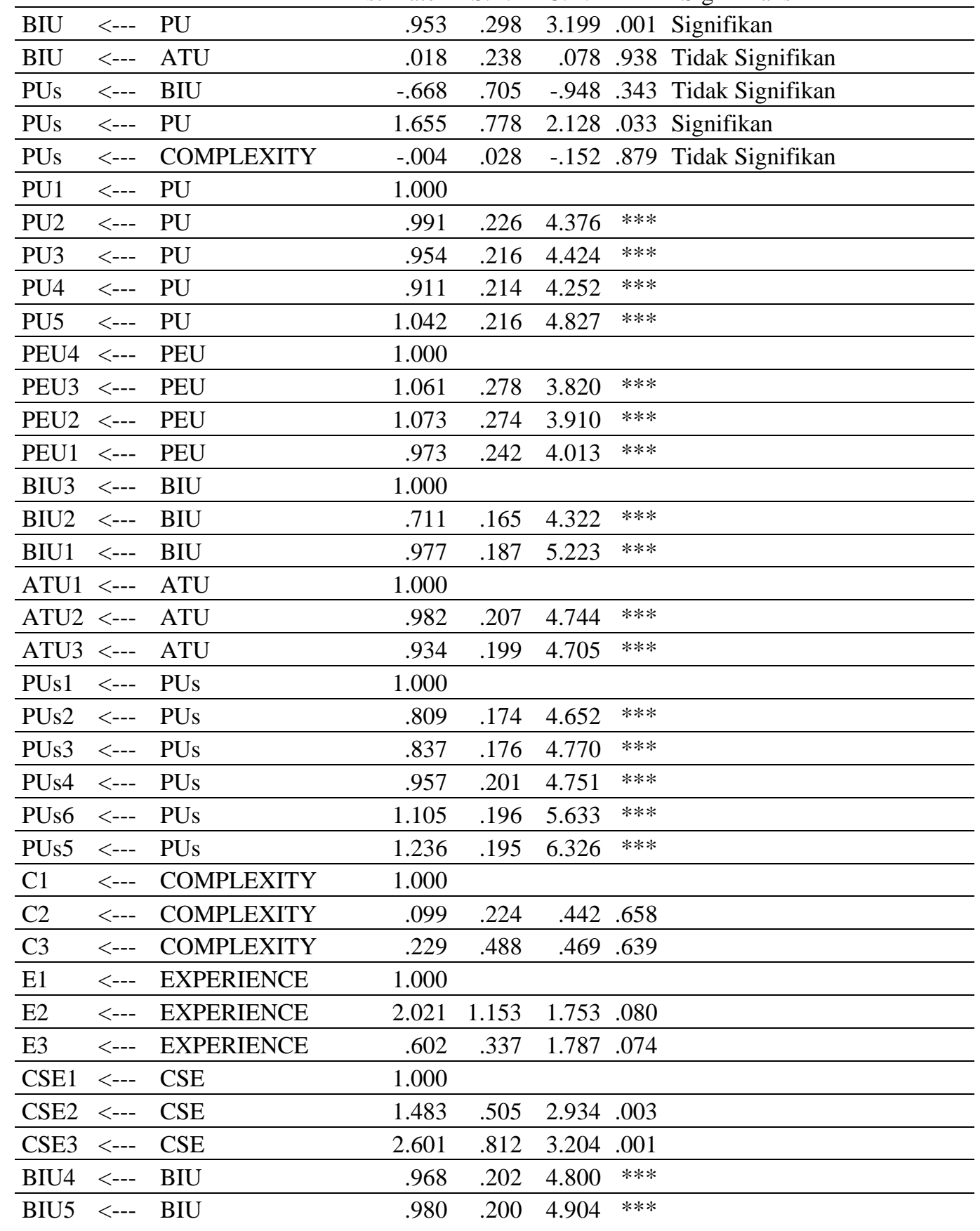

Sumber: Hasil olah data

Tabel diatas menunjukkan terdapat beberapa model hubungan yang tidak signifikan sehingga perlu dilakukan modifikasi. Hubungan yang tidak signifikan dapat dilihat pada nilai $\mathrm{P}$, jika nilai $\mathrm{P}$ kurang dari 0,10 atau dengan simbol $* * *$ maka hubungan dinyatakan signifikan. Sedangkan jika nilai $\mathrm{P}$ lebih besar dari 0,10 maka hubungan dinyatakan tidak signifikan. Berdasarkan hasil output regression weights diatas terdapat 3 hubungan yang tidak signifikan karena nilai $\mathrm{P}>0,10$ yaitu hubungan konstruk CSE terhadap PU, Experience terhadap PU, Complexity terhadap PU, PEU terhadap ATU, ATU terhadap BIU, BIU terhadap Pus, dan Complexity terhadap PUs. 


\section{Pengujian Hipotesis dengan SEM}

Hipotesis penelitian yang akan diuji berdasarkan model penelitian yang telah dikembangkan. Pengujian dilakukan untuk melihat hubungan di antara konstruk yang ada pada model. Dasar pengambilan keputusan diambil dengan melihat bobot regresi untuk konstruk terkait pada hasil pengujian model dari SPSS AMOS versi 22. Jika P > 0,10 maka $\mathrm{H}_{0}$ diterima dan jika $\mathrm{P}<0,10$ dan dilambangkan dengan *** maka $\mathrm{H}_{0}$ ditolak.

Tabel 7.

Nilai Regression Weight Model Penelitian

\begin{tabular}{|c|c|c|c|c|c|c|c|}
\hline & & & $\begin{array}{c}\text { Estim } \\
\text { ate }\end{array}$ & S.E. & C.R. & $\mathrm{P}$ & $\begin{array}{c}\text { Signifi } \\
\text { kansi }\end{array}$ \\
\hline PEU & $<---$ & CSE & 1.327 & .474 & 2.801 & .005 & $\begin{array}{c}\text { Signifi } \\
\text { kan }\end{array}$ \\
\hline PU & $<---$ & $\mathrm{CSE}$ & -.128 & .285 & -.449 & .654 & $\begin{array}{c}\text { Tidak } \\
\text { Signifi } \\
\text { kan } \\
\end{array}$ \\
\hline PU & $<---$ & $\begin{array}{c}\text { EXP } \\
\text { ERIE } \\
\text { NCE }\end{array}$ & .184 & .132 & 1.390 & .164 & $\begin{array}{c}\text { Tidak } \\
\text { Signifi } \\
\text { kan }\end{array}$ \\
\hline PU & $<---$ & $\begin{array}{c}\text { COM } \\
\text { PLE } \\
\text { XITY }\end{array}$ & .011 & .027 & .393 & .694 & $\begin{array}{c}\text { Tidak } \\
\text { Signifi } \\
\text { kan }\end{array}$ \\
\hline PU & $<---$ & PEU & 1.187 & .334 & 3.553 & $* * *$ & $\begin{array}{c}\text { Signifi } \\
\text { kan }\end{array}$ \\
\hline ATU & $<---$ & PU & 2.644 & $\begin{array}{c}1.36 \\
6 \\
\end{array}$ & 1.936 & .053 & $\begin{array}{c}\text { Signifi } \\
\text { kan }\end{array}$ \\
\hline ATU & $<---$ & PEU & 1.980 & $\begin{array}{c}1.53 \\
2\end{array}$ & $\begin{array}{c}- \\
1.292\end{array}$ & .196 & $\begin{array}{c}\text { Tidak } \\
\text { Signifi } \\
\text { kan }\end{array}$ \\
\hline BIU & $<---$ & PU & .953 & .298 & 3.199 & .001 & $\begin{array}{c}\text { Signifi } \\
\text { kan }\end{array}$ \\
\hline BIU & $<---$ & ATU & .018 & .238 & .078 & .938 & $\begin{array}{c}\text { Tidak } \\
\text { Signifi } \\
\text { kan }\end{array}$ \\
\hline PUs & $<---$ & BIU & -.668 & .705 & -.948 & .343 & $\begin{array}{c}\text { Tidak } \\
\text { Signifi } \\
\text { kan }\end{array}$ \\
\hline PUs & $<---$ & PU & 1.655 & .778 & 2.128 & .033 & $\begin{array}{c}\text { Signifi } \\
\text { kan }\end{array}$ \\
\hline PUs & $<---$ & $\begin{array}{l}\text { COM } \\
\text { PLE } \\
\text { XITY }\end{array}$ & -.004 & .028 & -.152 & .879 & $\begin{array}{c}\text { Tidak } \\
\text { Signifi } \\
\text { kan }\end{array}$ \\
\hline
\end{tabular}




\section{Tabel 8}

Hasil Pengujian Hipotesis Penelitian

\begin{tabular}{|c|c|c|c|}
\hline No & Hipotesis $\left(\mathrm{H}_{0}\right)$ & $\mathrm{P}$ & Keterangan \\
\hline 1 & $\begin{array}{l}\text { Behavioral Intention to Use berpengaruh signifikan } \\
\text { terhadap Perceived Usage }\end{array}$ & ,343 & $\mathrm{H}_{0}$ diterima \\
\hline 2 & $\begin{array}{l}\text { Perceived Usefulness berpengaruh signifikan terhadap } \\
\text { Perceived Usage }\end{array}$ &, 033 & $\mathrm{H}_{0}$ ditolak \\
\hline 3 & $\begin{array}{l}\text { Perceived Usefulness berpengaruh signifikan terhadap } \\
\text { Behavioral Intention to Use }\end{array}$ &, 001 & $\mathrm{H}_{0}$ ditolak \\
\hline 4 & $\begin{array}{l}\text { Perceived Usefulness berpengaruh signifikan terhadap } \\
\text { Attitude Toward using }\end{array}$ &, 053 & $\mathrm{H}_{0}$ ditolak \\
\hline 5 & $\begin{array}{l}\text { Perceived Ease of Use berpengaruh signifikan terhadap } \\
\text { Perceived Usefulness }\end{array}$ & $* * *$ & $\mathrm{H}_{0}$ ditolak \\
\hline 6 & $\begin{array}{l}\text { Attitude Toward Using berpengaruh signifikan terhadap } \\
\text { Behavioral Intention to Use }\end{array}$ & ,938 & $\mathrm{H}_{0}$ diterima \\
\hline 7 & $\begin{array}{l}\text { Perceived Ease of Use berpengaruh signifikan terhadap } \\
\text { Attitude Toward Using }\end{array}$ & ,196 & $\mathrm{H}_{0}$ diterima \\
\hline 8 & $\begin{array}{l}\text { Experience berpengaruh signifikan terhadap Perceived } \\
\text { Usefulness }\end{array}$ &, 164 & $\mathrm{H}_{0}$ diterima \\
\hline 9 & $\begin{array}{l}\text { Complexity berpengaruh signifikan terhadap Perceived } \\
\text { Usefulness }\end{array}$ & ,694 & $\mathrm{H}_{0}$ diterima \\
\hline 10 & $\begin{array}{l}\text { Complexity berpengaruh signifikan terhadap Perceived } \\
\text { Usage }\end{array}$ &, 879 & $\mathrm{H}_{0}$ diterima \\
\hline 11 & $\begin{array}{l}\text { Computer Self Efficacy berpengaruh signifikan terhadap } \\
\text { Perceived Usefulness }\end{array}$ & ,654 & $\mathrm{H}_{0}$ diterima \\
\hline 12 & $\begin{array}{l}\text { Self Efficacy berpengaruh signifikan terhadap Perceived } \\
\text { Ease of Use }\end{array}$ &, 005 & $\mathrm{H}_{0}$ ditolak \\
\hline
\end{tabular}

Berdasarkan tabel diatas terdapat hipotesis $\left(\mathrm{H}_{0}\right)$ yang diterima di antaranya Behavioral Intention to Use berpengaruh signifikan terhadap Perceived Usage, Attitude Toward Using berpengaruh signifikan terhadap Behavioral Intention to Use, Perceived Ease of Use berpengaruh signifikan terhadap Attitude Toward Using, Experience berpengaruh signifikan terhadap Perceived Usefulness, Complexity berpengaruh signifikan terhadap Perceived Usefulness, Complexity berpengaruh signifikan terhadap Perceived Usage, dan Computer Self Efficacy berpengaruh signifikan terhadap Perceived Usefulness. Sedangkan hipotesis $\left(\mathrm{H}_{0}\right)$ yang ditolak adalah Perceived Usefulness berpengaruh signifikan terhadap Perceived Usage, Perceived Usefulness berpengaruh signifikan terhadap Behavioral Intention to Use, Perceived Usefulness berpengaruh signifikan terhadap Attitude Toward using, Perceived Ease of Use berpengaruh signifikan terhadap Perceived Usefulness, dan Self Efficacy berpengaruh signifikan terhadap Perceived Ease of Use.

\section{Kesimpulan}

Berdasarkan hasil pengujian terhadap penelitian yang dilakukan di PTKIS Jawa Barat dan Banten tentang tingkat penerimaan operator PTKIS terhadap aplikasi EMIS menggunakan pendekatan model penerimaan teknologi (Technology Acceptance Model) dengan menggunakan aplikasi AMOS versi 22.0. 
Terdapat delapan (8) konstruk/variabel pada penelitian ini yang dianggap dapat menganalisis tingkat penerimaan operator PTKIS terhadap EMIS di Jawa Barat dan Banten. Konstruk/variabel tersebut adalah Perceived Usefulness, Perceived Ease of Use, Behavioral Intention to Use, Attitude Toward Using, Perceived Usage, Experience, Complexity, dan self Efficacy dengan 12 hipotesis yang dibuat untuk menganalisa tingkat penerimaan operator PTKIS di Jawa Barat dan Banten.

Setelah dilakukan uji kuesioner yang valid dan reliabel, kemudian penyebaran kuesioner kepada responden yang merupakan operator PKTIS di Jawa Barat dan Banten, data yang diperoleh dari kuesioner tersebut memberikan hipotesa dari model konseptual penelitian. Hasil dari hipotesis tersebut adalah sebagai berikut: Behavioral intention to use berpengaruh signifikan terhadap Perceived usage, Perceived usefulness berpengaruh signifikan terhadap Perceived usage, Perceived usefulness berpengaruh signifikan terhadap Behavioral intention to use, Perceived usefulness berpengaruh signifikan terhadap Attitude toward using, Perceived ease of use berpengaruh signifikan terhadap Perceived Usefulness, Attitude toward using tidak berpengaruh signifikan terhadap Behavioral intention to use, Perceived ease of use tidak berpengaruh signifikan terhadap Attitude toward using, Experience tidak berpengaruh signifikan terhadap Perceived usefulness Complexity tidak berpengaruh signifikan terhadap Perceived usefulness, Complexity tidak berpengaruh signifikan terhadap Perceived usage, Self Efficacy tidak berpengaruh signifikan terhadap Perceived usefulness, dan Self Efficacy berpengaruh signifikan terhadap Perceived ease of use 


\section{BIBLIOGRAFI}

Chau, P. Y. K., \& Hu, P. J.-H. (2002). Investigating healthcare professionals' decisions to accept telemedicine technology: an empirical test of competing theories. Information \& Management, 39(4), 297-311.

Davis, F. D., Bagozzi, R. P., \& Warshaw, P. R. (1989). User acceptance of computer technology: a comparison of two theoretical models. Management Science, 35(8), 982-1003.

Gardner, C., \& Amoroso, D. L. (2004). Development of an instrument to measure the acceptance of internet technology by consumers. 37th Annual Hawaii International Conference on System Sciences, 2004. Proceedings of The, 10-pp. IEEE.

Gefen, D., Karahanna, E., \& Straub, D. W. (2003). Trust and TAM in online shopping: An integrated model. MIS Quarterly, 27(1), 51-90.

Ghozali, I. (2005). Analisis Multivariate dengan program SPSS. Semarang: Badan Penerbit Universitas Diponegoro.

Henderson, R., \& Divett, M. J. (2003). Perceived usefulness, ease of use and electronic supermarket use. International Journal of Human-Computer Studies, 59(3), 383395.

Igbaria, M. (1994). An examination of the factors contributing to microcomputer technology acceptance. Accounting, Management and Information Technologies, 4(4), 205-224.

Jogiyanto, Hartono M. (2007). Sistem informasi keperilakuan. Yogyakarta: Andi Offset.

Jogiyanto, Hartono Mustakini. (2005). Sistem teknologi informasi. Andi. Yogyakarta.

Karahanna, E., Straub, D. W., \& Chervany, N. L. (1999). Information technology adoption across time: a cross-sectional comparison of pre-adoption and postadoption beliefs. MIS Quarterly, 183-213.

Mulgan, G., \& Albury, D. (2003). Innovation in the public sector. Strategy Unit, Cabinet Office, 1(1), 40.

Straub, D., Limayem, M., \& Karahanna-Evaristo, E. (1995). Measuring system usage: Implications for IS theory testing. Management Science, 41(8), 1328-1342. 
Ayu Puji Rahayu

Sun, H., \& Zhang, P. (2006). The role of moderating factors in user technology acceptance. International Journal of Human-Computer Studies, 64(2), 53-78.

Tok, B. R., \& Sora, M. (2013). Perspective of emerging integrating technology (ICT) in learning and teaching. International Journal of Information and Education Technology, 3(2), 282. 